\title{
Pengaruh Kepuasan dan Kepercayaan terhadap Loyalitas Penumpang Maskapai Garuda Indonesia di Bandar Udara Adi Soemarmo
}

\author{
Arif Fakhrudin \\ Manajemen Transportasi, Sekolah Tinggi Teknologi Kedirgantaraan, Indonesia \\ Korespondnsi penulis: ariffakhrudin21@gmail.com
}

\begin{abstract}
Customer loyalty has been a discussion issue for managers, consultants, and academics interest. Optimal service quality is expected to meet customer expectations so that conditions will create customer satisfaction and loyalty. This study aims to determine the effect of satisfaction and trust on Garuda Indonesia airline passenger loyalty at Adi Soemarmo Airport, Boyolali, Central Java, Indonesia. This type of research is quantitative research. The data used in this study are primary data obtained by distributing questionnaires to Garuda Indonesia airline passengers at Adi Soemarmo Airport, Boyolali. Of the 100 questionnaires distributed to respondents, the response rate of this research reached $68 \%$. The analysis of the data used in this study is multiple linear regression analysis using SPSS version 20 as a data processing aid. The results show that the loyalty of Garuda Indonesia airline passengers is significantly influenced by their satisfaction and trust, partially and simultaneously.
\end{abstract}

Keywords: Satisfaction; Trust; Loyalty; Garuda Indonesia.

\begin{abstract}
Abstrak. Loyalitas pelanggan telah menjadi topi perbincangan menarik bagi para manajer, konsultan, dan akademisi. Kualitas layanan yang optimal diharapkan mampu memenuhi harapan pelanggan, sehingga kondisi tersebut dapat menciptakan kepuasan dan loyalitas pelanggan. Penelitian ini bertujuan untuk menguji pengaruh kepuasan dan kepercayaan terhadap loyalitas penumpang maskapai Garuda Indonesia di Bandar Udara (Bandara) Adi Soemarmo, Boyolali, Jawa Tengah, Indonesia. Jenis penelitian ini adalah penelitian kuantitatif. Data yang digunakan dalam penelitian ini merupakan data primer yang diperoleh melalui pembagian kuesioner kepada penumpang maskapai Garuda Indonesia di Bandara Adi Soemarmo, Boyolali. Dari 100 kuesioner yang dibagikan kepada responden, response rate penelitian ini mencapai $68 \%$. Teknik analisis data yang diterapkan dalam penelitian ini adalah analisis regresi linier berganda menggunakan SPSS versi 20 sebagai alat bantu pengolahan data. Hasil penelitian menunjukkan bahwa loyalitas penumpang maskapai penerbangan Garuda Indonesia dipengaruhi secara signifikan oleh kepuasan dan kepercayaan mereka, baik secara parsial dan simul$\tan$.
\end{abstract}

Kata Kunci: Kepuasan; Kepercayaan; Loyalitas; Garuda Indonesia. 
Article Info:

Received: March 18, 2020

\section{LATAR BELAKANG}

Persaingan dunia usaha tidak hanya ditimbulkan oleh faktor globalisasi, tetapi kondisi tersebut dipicu pula oleh konsumen yang semakin cerdas dan banyak tuntutan permintaan. Pada umumnya, produk atau jasa yang dapat dipercaya dan memuaskan yang biasanya diinginkan oleh para konsumen. Kompetisi dengan intensitas yang semakin tinggi memicu perusahaan lebih mengarah akan keinginan konsumen dengan cara lebih hati-hati, teliti dan bukan meletakkannya pada sudut pandang perusahaan semata (Harumi, 2016). Menurut Fihartini (2012), banyaknya konsumen yang setia menandai kesusksesan sebuah perusahaan. Pada saat konsumen setia kepada perusahaan, mereka akan berbelanja dan menggunakannya secara berulang. Peran usaha sebagai penyedia jasa yang berkualitas bagi masyarakat merupakan salah satu kunci keberhasilan usaha. Setiap perusahaan berupaya keras agar mampu merebut simpati calon pelanggan untuk menggunakan jasa mereka akibat persaingan bisnis yang makin kompetitif (Hariyatiningsih, Suddin, \& Ernawati, 2016).

Kotler (2010a) menyebutkan bahwa kepuasan pelanggan adalah perasaan senang atau menyesal yang berawal dari membandingkan antara kinerja produk atau jasa dengan keinginannya. Pelanggan akan melakukan pembelian ulang karena merasa senang terhadap kinerja perusahaan. Reaksi positif pelanggan berdampak besar pada keberlangsungan hubungan jangka panjang yang ditimbulkan karena pengalamannya bertransaksi dengan perusahaan tersebut (Ermawati, Sudiro \& Khusniyah, 2016). Menurut Muktiono (2014), kepuasan pelanggan dapat mendorong suatu tindakan setelah ia memakai produk maupun jasa perusahaan. Pelanggan yang merasa senang akan memakai kembali produk atau jasa yang ditawarkan perusahaan. Peningkatan loyalitas konsumen dan upaya mencegah tingkat perputaran merek, mengurangi sensitifitas konsumen terhadap harga, mengurangi biaya kegagalan pemasaran, mengurangi biaya operasional yang diakibatkan oleh meningkatnya jumlah konsumen, meningkatkan efektivitas iklan, dan meningkatkan reputasi bisnis perusahaan merupakan tindakantindakan konsumen akibat tingkat kepuasan konsumen yang tinggi (Soegoto, 2013).

Reyhan (2013), kepercayaan adalah keyakinan dimana agen sebagai alat untuk mewujudkan hubungan terus - menerus dengan konsumennya. Menurut Hariyatiningsih et al. (2016), perusahaan tidak dapat membangun hubungan tanpa adanya kepercayaan, oleh sebab itu kepercayaan sangat penting. Selain itu, pelanggan dijanjikan atas produk atau jasa yang tidak dapat dilihat meskipun pelanggan harus membayar sebelum merasakan produk atau jasa tersebut. Oleh karena itu, kepercayaan juga memiliki makna penting bagi perusahaan penyedia jasa.

Transportasi adalah kegiatan memindahkan orang atau barang dari satu lokasi ke lokasi lain, sedangkan transportasi udara merupakan salah satu sarana transportasi yang perkembangannya semakin hari semakin pesat (Ginting, 2005). Perkembangan tersebut dipengaruhi oleh karakteristik Indonesia sebagai sebuah negara kepulauan yang terdiri atas ribuan pulau besar dan kecil yang dikelilingi lautan. Oleh karena itu, sarana transportasi udara untuk menghubungkan antarpulau di Indonesia dengan lebih cepat 
sangat diperlukan. Organisasi yang menyediakan jasa transportasi udara atau penerbangan bagi penumpang dan barang disebut maskapai (Ginting, 2005). Maskapai dapat menyediakan jasa penerbangan dengan membentuk kerja sama atau aliansi dengan maskapai lainnya demi keuntungan bersama (Ginting, 2005).

Dibandingkan maskapai penerbangan lainya, PT Garuda Indonesia merupakan Badan Usaha Milik Negara (BUMN) di bidang jasa penerbangan yang mengunggulkan kualitas layanan (Hariyatiningsih et al., 2016). Jasa layanan penerbangan yang ditawarkannya mengutamakan kenyamanan dalam perjalanan dan keselamatan selama penerbangan. Maskapai Garuda Indonesia mengharapkan pelanggan merasa senang dan mempunyai citra yang baik terhadap layanan perusahaan, sehingga perusahaan mengharapkan pelanggannya akan menggunakan layanannya secara terus menerus (Hariyatiningsih et al., 2016). Di sisi lain, ketatnya persaingan bisnis airlines, baik dalam lingkup pasar domestik maupun internasional. Hal tersebut menuntut perusahaan untuk selalu memberikan layanan terbaik demi menjaga loyalitas konsumen (Handoyo, 2011).

Permasalahan yang terjadi saat ini adalah semakin ketatnya persaingan maskapai penerbangan untuk menarik perhatian penumpang. Lion Air adalah salah satu pesaing terbesar bagi Garuda Indonesia yang lebih mengedepankan tarif penerbangan low cost (Hariyatiningsih et al., 2016). Dengan permasalahan tersebut, manajemen Garuda Indonesia tetap fokus pada peningkatan kualitas layanan dengan strategi full service, sehingga upaya tersebut lebih ditujukan untuk mempertahankan pelanggan agar tetap setia dengan jasa penerbangan Garuda Indonesia (Hariyatiningsih et al., 2016). Mengingat pentingnya loyalitas pelanggan, maskapai Garuda Indonesia seharusnya mampu memberikan kepuasan secara optimal bagi penumpangnya dan memperkuat citranya melalui perbandingan dengan jasa penerbangan perusahaan lain, sehingga kondisi tersebut akan semakin memperjelas citra maskapai Garuda Indonesia di mata pelanggannya.

Loyalitas penumpang dan image positif perusahaan dapat dicapai, apabila layanan yang diperoleh penumpang berkualitas dan memberikan kepuasan maksimal bagi mereka (Hariyatiningsih et al., 2016). Kondisi tersebut melatarbelakangi pentingnya penelitian ini untuk menganalisis faktor-faktor yang mempengaruhi loyalitas penumpang. Penelitian ini fokus pada dua variabel penting yang dapat mempengaruhi loyalitas pelanggan, yaitu kepuasan dan kepercayaan mereka terhadap layanan penerbangan Garuda Indonesia. Fokus tersebut dilakukan untuk mengungkap pengaruhvariabel tersebut terhadap penumpang Garuda Indonesia di Bandar Udara Adi Soemarmo, Kabupaten Boyolali, Provinsi Jawa Tengah. Berdasarkan uraian diatas, tujuan penelitian ini adalah upaya untuk mengetahui loyalitas penumpang maskapai penerbangan Garuda Indonesia yang dipengaruhi oleh kepuasan dan kepercayaan penumpang secara parsial dan simultan.

\section{KAJIAN TEORITIS}

\section{Pemasaran}

Pemasaran diartikan sebagai sebuah proses sosial yang terjadi, ketika seseorang atau sekelompok orang memperoleh apa yang mereka butuhkan dan inginkan melalui penciptaan nilai dan pertukaran produk dengan pihak lain (Kotler, 2010b). Menurut 
Soegoto (2013), pemasaran adalah tindakan pertukaran yang mampu memuaskan tujuan individu dan organisasi melalui pentahapan proses dari tindakan merencanakan dalam menjalankan konsep, harga, promosi, dan distribusi atas sejumlah ide, barang dan jasa. Menurut Maharani (2010), manajemen pemasaran adalah tindakan menciptakan pertukaran yang diinginkan dengan pasar sasaran dalam pencapaian tujuan organisasi melalui proses analisis, penyusunan rencana, kegiatan pelaksanaan, dan pengendalian program-program pemasaran perusahaan.

\section{Kepuasan Konsumen}

Menurut Hasan (2009), kepuasan konsumen adalah suatu persepsi atas suatu produk, baik barang atau pun jasa yang memberikan kepuasan kepadanya apabila terpenuhi harapannya. Kepuasan merupakan perasaan yang timbul ketika konsumen membandingkan persepsi mereka antara kinerja produk atau jasa yang lebih tinggi daripada harapan mereka (Maharani, 2010). Kepuasan dapat mendorong tindakan pelanggan untuk memakai ulang produk maupun jasa yang ditawarkan perusahaan. Pelanggan yang puas cenderung akan memakai kembali produk atau jasa yang ditawarkan perusahaan (Muktiono, 2014).

Menurut pendapat Kotler (2010a), kepuasan adalah perasaan senang seseorang yang muncul setelah ia membandingkan antara kinerja produk yang ia pikirkan dan kinerja atau hasil yang ia harapkan. Apabila kinerja berada di bawah harapan pelanggan, maka ia akan merasa tidak puas. Sebaliknya, apabila kinerja sesuai atau melebihi harapan, maka pelanggan akan merasa puas atau sangat puas. Selanjutnya, Endarwita (2013) menjelaskan bahwa biaya untuk mempertahankan pelanggan yang sudah ada akan jauh lebih murah daripada biaya untuk mencari pelanggan baru. Untuk maksud tersebut, retensi konsumen (consumer retention) merupakan salah satu upaya perusashaan untuk meningkatkan kinerja produknya. Prasetyo (2013) menyatakan bahwa respon konsumen terhadap evaluasi ketidaksesuaian (disconfirmation) yang mereka rasakan antara harapan dan kinerja aktual suatu produk atau jasa adalah sebuah tanggapan emosional terhadap evaluasi pengalaman konsumsi.

Penelitian Harumi (2016) mengemukakan bahwa kepuasan yang baik akan mempengaruhi loyalitas pelanggan. Selanjutnya, pencapaian kepuasan pelanggan dapat mempengaruhi terjadinya pembelian secara kontinyu dalam jangka panjang. Sebaliknya, pada tingkat kepuasan yang rendah, maka pelanggan akan merasa kecewa dan cenderung berpindah ke merek lain. Penelitian Hariyatiningsih et al. (2016) menyatakan bahwa loyalitas konsumen dipengaruhi oleh kepuasan mereka secara signifikan. Dari uraian tersebut, penelitian ini mengajukan hipotesis kesatu (H1) sebagai berikut:

\section{H1: Ada pengaruh kepuasan secara parsial terhadap loyalitas penumpang Maska- pai Garuda Indonesia di Bandar Udara Adi Soemarmo.}

\section{Kepercayaan}

Menurut Winahyuningsih (2010), kepercayaan adalah faktor penting yang mendasari berdirinya suatu bisnis. Organisasi bisnis atau perusahaan akan berjalan baik apabila ada kepercayaan dari konsumen terhadap produk atau jasa yang ditawarkannya. Menurut Laely (2016), kepercayaan adalah kehendak hati seseorang untuk bertopang pada orang lain ketika ia memiliki keseriusan pada orang tersebut. Ketika seseorang mengambil keputusan, maka ia akan memutuskan berdasarkan pilihan orang-orang yang 
ia percaya. Kepercayaan merupakan kesesuaian antara individu dan pihak lain yang menghasilkan keyakinan kepada pihak lain tersebut (Prasetyo, 2013).

Menurut Maharani (2010), kepercayaan merupakan manifestasi keyakinan seseorang untuk memperoleh apa yang ia inginkan pada mitra pertukarannya. Arzena (2013) menyatakan bahwa kepercayaan adalah sebuah keadaan ketika salah satu pihak dalam proses pertukaran merasa yakin atas integritas pihak lain, sedangkan Harumi (2016) menyatakan bahwa kepercayaan adalah keyakinan terhadap agen yang memakainya sebagai alat untuk menjalin hubungan dalam waktu yang lama dengan konsumennya. Nidyatantri, Suryawardani, \& Agung (2016) menyebutkan bahwa kepercayaan konsumen menggambarkan perasaan percaya yang bersifat psikologis terhadap suatu produk, baik secara fisik maupun manfaatnya, termasuk janji-janji atas merek tersebut. Menurut Prasetyo (2013), kepercayaan diartikan sebagai kesediaan individu bergantung pada pihak lain dalam pertukaran atas dasar keyakinannya.

Hasil penelitian Nidyatantri et al. (2016) menemukan bahwa kepuasan dan kepercayaan menghasilkan pengaruh kuat terhadap loyalitas pelanggan. Hal itu menunjukkan bahwa loyalitas konsumen akan meningkat, karena tingkat kepuasan dan kepercayaan mereka semakin tinggi. Penelitian Harumi (2016) mengemukakan bahwa kepercayaan yang baik akan mempengaruhi loyalitas pelanggan. Kepercayaan yang baik akan mempengaruhi terjadinya pembelian secara kontinu dalam waktu yang lama. Sebaliknya, ketika tingkat kepercayaan rendah, maka pelanggan cenderung merasa kecewa dan akan berpindah ke merek lain. Dari uraian tersebut, maka penelitian ini mengajukan hipotesis kedua $(\mathrm{H} 2)$ sebagai berikut:

\section{H2: Ada pengaruh kepercayaan secara parsial terhadap loyalitas penumpang Maskapai Garuda Indonesia di Bandar Udara Adi Soemarmo.}

\section{Loyalitas}

Loyalitas adalah komitmen seorang konsumen dalam penggunaan produk, sehingga ia akan melakukan pembelian berulang dan setia membeli produk tersebut (Boohene \& Agyapong, 2011). Loyalitas konsumen merupakan komitmen kuat untuk membeli kembali produk atau jasa yang ia sukai di masa depan, meskipun faktor situasi dan usaha-usaha pemasaran lainnya dapat berpotensi mempengaruhinya untuk beralih (Hasan, 2009). Menurut Arzena (2013), loyalitas konsumen adalah sikap jujur konsumen ketika merasakan kepuasan atas pembelian suatu produk atau jasa, sehingga ia berpotensi untuk membeli produk tersebut secara berulang-ulang dalam hubungan jangka panjang.

Menurut Prasetyo (2013), loyalitas konsumen adalah penilaian atas layanan yang berkualitas tinggi, sehingga niat perilakunya cenderung bersifat positif melalui peningkatan hubungan jangka panjang dengan perusahaan. Loyalitas konsumen merupakan wujud kepuasan konsumen dalam menggunakan produk maupun jasa layanan perusahaan, sehinga ia akan bertahan menjadi pelanggan setia perusahaan tersebut (Endarwita, 2013). Harumi (2016) menyatakan bahwa loyalitas adalah komitmen pelanggan atas merek produk berdasarkan sikap positif yang tercermin dalam pembelian ulang secara konsisten. Loyalitas terhadap merek akan berkembang mengikuti empat tahapan, yaitu kognitif, afektif, konatif, dan tindakan (Maharani, 2010). Dari uraian tersebut, penelitian ini mengajukan hipotesis ketiga (H3) sebagai berikut: 


\section{H3: Ada pengaruh kepuasan dan kepercayaan secara simultan terhadap loyalitas penumpang Maskapai Garuda Indonesia di Bandar Udara Adi Soemarmo.}

\section{Model Penelitian}

Penelitian ini dimaksudkan untuk membuktikan pengaruh variabel independen terhadap variabel dependen. Variabel independen tersebut adalah kepuasan dan kepercayaan penumpang, sedangkan variabel dependennya adalah loyalitas penumpang Maskapai Garuda Indonesia. Hubungan antarvariabel tersebut digambarkan dalam model penelitian yang ditunjukkan pada Gambar 1.

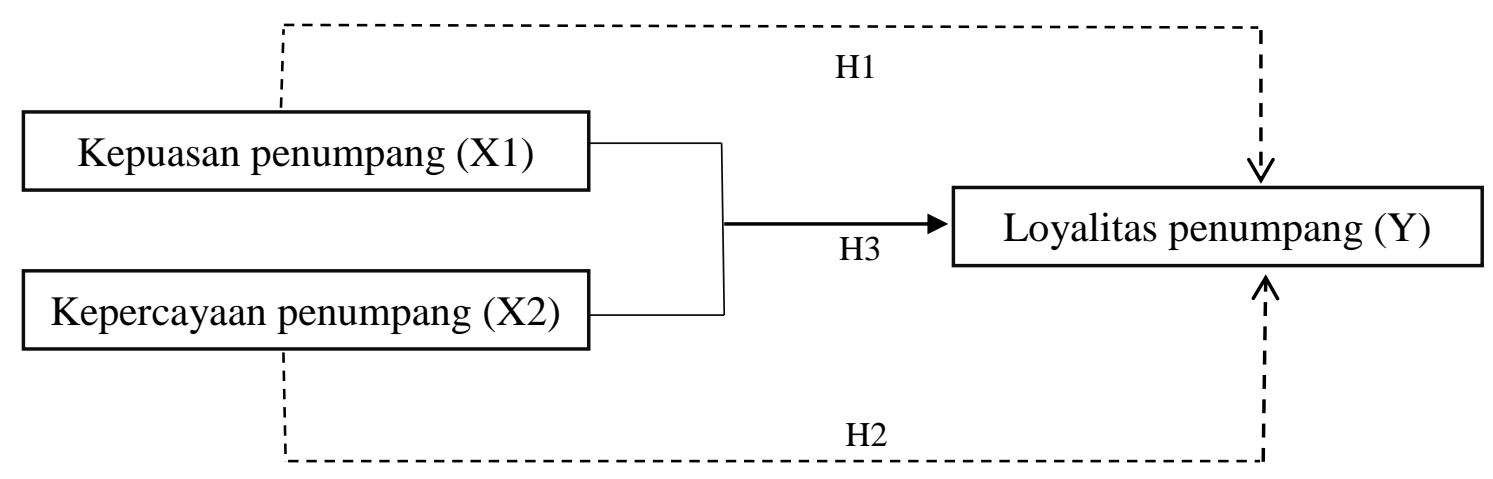

Keterangan:

\section{Gambar 1. Model Penelitian}

$-\cdots--\rightarrow>$ = pengaruh parsial $(\mathrm{H} 1$ dan $\mathrm{H} 2)$.

$\rightarrow=$ pengaruh simultan $(\mathrm{H} 3)$.

\section{METODE PENELITIAN}

Jenis penelitian ini adalah penelitian kuantitatif dengan metode survey yang menggunakan kuesioner sebagai instrumen penelitian untuk mengumpulkan data primer. Penelitian ini mengkaji pengaruh variabel independen secara parsial dan simultan terhadap variabel dependen, yaitu pengaruh kepuasan (X1) dan kepercayaan (X2) terhadap loyalitas penumpang (Y). Teknik pengambilan sampel yang digunakan dalam penelitian ini adalah purposive sampling, yaitu teknik penentuan sampel yang memberikan kebebasan kepada peneliti untuk memilih sampel sesuai kriteria tertentu (Priyatno, 2010). Kriteria sampel dalam penelitian ini adalah pelanggan yang sudah pernah menggunakan layanan jasa maskapai penerbangan Garuda Indonesia sebelumnya. Definisi operasional variabel, indikator, dan skala pengukuran setiap variabel dalam penelitian ini disajikan secara rinci pada Tabel 1. Penelitian ini juga menggunakan uji validitas dan reliabilitas instrumen penelitian untuk mendapatkan hasil penelitian yang valid dan reliabel.

\section{HASIL PENELITIAN DAN PEMBAHASAN}

\section{Analisis Responden}


Dalam penelitian ini, responden yang dipilih adalah penumpang maskapai penerbangan Garuda Indonesia di Bandar Udara Adi Soemarmo, Boyolali. Untuk menentukan jumlah sampel, peneliti berpedoman pada pendapat Roscoe dalam Sugiyono (2010) yang menyebutkan bahwa ukuran sampel lebih besar dari 30 dan kurang dari 500 sudah mencukupi untuk suatu penelitian. Jumlah kuesioner yang dibagikan kepada responden sebanyak 100 buah. Dari jumlah tersebut, kuesioner yang tidak dapat digunakan lebih lanjut mencapai 32 buah, karena berbagai faktor, seperti adanya jawaban ganda dan tidak adanya pilihan jawaban, sehingga response rate penelitian ini mencapai $68 \%$.

Tabel 1. Definisi, Indikator, dan Skala Pengukuran Variabel Penelitian

\begin{tabular}{|c|c|c|c|c|}
\hline No & Variabel & Definisi Operasional & Indikator & Skala Pengukuran \\
\hline 1 & $\begin{array}{l}\text { Kepuasan } \\
\text { penumpang }\end{array}$ & $\begin{array}{l}\text { Kepuasan merupakan } \\
\text { suatu perasaan didalam } \\
\text { diri para konsumen } \\
\text { terhadap apa yang telah } \\
\text { diperoleh dan dirasakan } \\
\text { ketika konsumen } \\
\text { menerima pelayanan. }\end{array}$ & $\begin{array}{l}\text { 1. Kebutuhan dan keinginan } \\
\text { pelanggan. } \\
\text { 2. Pengalaman masa lalu. } \\
\text { 3. Pengalaman teman-teman. } \\
\text { 4. Kualitas layanan. } \\
\text { 5. Faktor emosional. } \\
\text { 6. Persepsi melihat kinerja. } \\
\text { 7. Penyediaan informasi pada } \\
\text { saat diminta. } \\
\text { 8. Sesuai dengan yang } \\
\text { diharapkan. }\end{array}$ & $\begin{array}{l}\text { Diukur dengan } \\
\text { menggunakan skala } \\
\text { Likert } 1-5 \text {. }\end{array}$ \\
\hline 2 & $\begin{array}{l}\text { Kepercayaan } \\
\text { penumpang }\end{array}$ & $\begin{array}{l}\text { Kepercayaan } \\
\text { merupakan } \\
\text { kepercayaan dari para } \\
\text { konsumen dalam } \\
\text { menggunakan produk } \\
\text { tersebut. }\end{array}$ & $\begin{array}{l}\text { 1. } \begin{array}{l}\text { Rasa percaya bahwa } \\
\text { perusahaan memberikan } \\
\text { informasi yang benar. }\end{array} \\
\text { 2. } \begin{array}{l}\text { Rasa percaya bahwa } \\
\text { perusahaan menanggapi } \\
\text { keluhan konsumen. }\end{array} \\
\text { 3. Rasa percaya bahwa } \\
\text { perusahaan memenuhi } \\
\text { janjinya. } \\
\text { Rasa percaya bahwa } \\
\text { produk yang ditawarkan } \\
\text { aman atau tidak berisiko. }\end{array}$ & $\begin{array}{l}\text { Diukur dengan } \\
\text { menggunakan skala } \\
\text { Likert } 1-5 \text {. }\end{array}$ \\
\hline 3 & $\begin{array}{l}\text { Loyalitas } \\
\text { penumpang }\end{array}$ & $\begin{array}{l}\text { Loyalitas merupakan } \\
\text { suatu ukuran } \\
\text { keterkaitan konsumen } \\
\text { berkaitan dengan } \\
\text { kualitas dari pelayanan } \\
\text { yang benar-benar } \\
\text { pelanggan rasakan. }\end{array}$ & $\begin{array}{ll}\text { 1. } & \text { Produk/jasa yang disukai. } \\
\text { 2. Produk/jasa yang bagus } \\
\text { 3. Kesetiaan terhadap } \\
\text { perusahaan (tidak tertarik } \\
\text { merek lain) } \\
\text { 4. Merekomendasikan citra } \\
\text { positif. } \\
\text { 5. Konsistensi pembelian } \\
\text { ulang. }\end{array}$ & $\begin{array}{l}\text { Diukur dengan } \\
\text { menggunakan skala } \\
\text { Likert } 1-5 .\end{array}$ \\
\hline
\end{tabular}

Sumber: Nugroho \& Sudaryanto (2013).

Gambaran umum karakteristik responden dalam penelitian ini ditampilkan dalam Tabel 2. Berdasarkan data pada Tabel 2 tersebut, mayoritas responden adalah laki-laki sebanyak $69 \%$, sedangkan $31 \%$ sisanya adalah perempuan. Selanjutnya, sebanyak $41 \%$ reponden menggunakan layanan maskapai penerbangan Garuda Indonesia lebih dari 6 kali dan sebagian besar responden berusia pada rentang 36-40 tahun sebanyak 46\%. 


\section{Uji Validitas dan Reliabilitas}

Uji validitas instrumen bertujuan untuk mengetahui sejauh mana ketepatan dan kecermatan alat ukur dalam menjalankan fungsi ukurnya dengan menggunakan koefisien korelasi product moment (Priyatno, 2010). Pengujian reliabilitas terhadap instrumen menggunakan Cronbach's alpha, yaitu formula yang digunakan untuk melihat sejauh mana alat ukur dapat memberikan hasil yang relatif tidak berbeda apabila dilakukan pengukuran kembali terhadap gejala yang sama pada saat yang berbeda (Priyatno, 2010).

Tabel 2. Karakteristik Responden

\begin{tabular}{llcc}
\hline \multicolumn{1}{c}{ Karekteristik Responden } & Kriteria & Jumlah $(\mathbf{n = 6 8})$ & Persentase \\
\hline \multirow{2}{*}{ Jenis Kelamin } & Laki-Laki & 47 & $69 \%$ \\
& Perempuan & 21 & $31 \%$ \\
\hline \multirow{2}{*}{ Penggunaan Layanan } & $2-4$ kali & 19 & $28 \%$ \\
& $4-6$ kali & 21 & $31 \%$ \\
& $>6$ kali & 28 & $41 \%$ \\
\multirow{2}{*}{ Usia } & $<20$ tahun & 11 & $16 \%$ \\
& $20-35$ tahun & 17 & $25 \%$ \\
\hline
\end{tabular}

Sumber: Data primer diolah (2019).

Hasil uji validitas menunjukkan bahwa delapan pernyataan untuk mengukur variabel kepuasan penumpang dinyatakan valid, sedangkan uji reliabilitas kepuasan menunjukkan koefisien Cronbach's alpha sebesar 0,816 yang berarti instrumen variabel kepuasan penumpang dinyatakan reliabel. Selanjutnya, keempat pernyataan untuk mengukur variabel kepercayaan penumpang juga dinyatakan valid, sedangkan uji reliabilitasnya menunjukkan bahwa koefisien Cronbach's alpha sebesar 0,768 yang menunjukkan instrumen variabel kepercayaan penumpang reliabel. Pengukuran variabel loyalitas penumpang menggunakan lima pernyataan yang dinyatakan valid dalam uji validitas, sedangkan uji reliabilitasnya menghasilkan koefisien Cronbach's alpha sebesar 0,627 yang menunjukkan bahwa instrumen loyalitas penumpang reliabel.

\section{Analisis Regresi Linier Berganda}

Analisis regresi linier berganda yang diolah menggunakan aplikasi SPSS versi 20, menghasilkan persaman regresi [1], sedangkan rinciannya ditampilkan di Tabel 3.

$$
\mathrm{Y}=\mathbf{7 , 6 8 0}+\mathbf{0 , 1 3 6} \mathrm{X} 1+\mathbf{0 , 2 1 1} \mathrm{X} 2
$$

Konstanta $(\alpha)$ sebesar 7,680 diartikan secara statistik bahwa apabila kepuasan dan kepercayaan tidak ada nilainya atau sama dengan 0 , maka nilai loyalitas penumpang sebesar 7,680. Koefisien regresi variabel kepuasan (X1) sebesar 0,136 menunjukkan bahwa apabila variabel kepuasan ditingkatkan 1 satuan, maka loyalitas penumpang akan terjadi peningkatan sebesar 0,136 satuan. Jika koefisien regresi tersebut bernilai positif, maka pengaruh kepuasan terhadap loyalitas penumpang bersifat positif atau meningkat dengan arah yang sama. Artinya, peningkatan kepuasan penumpang dapat berpengaruh pada peningkatan loyalitas penumpang maskapai penerbangan Garuda Indonesia. 
Koefisien regresi variabel kepercayaan (X2) sebesar 0,211. Koefisien tersebut menunjukkan bahwa apabila variabel kepercayaan ditingkatkan 1 satuan, maka loyalitas penumpang mengalami kenaikan sebesar 0,211 satuan. Koefisien regresi variabel kepercayaan bernilai positif menunjukkan bahwa perubahan kepercayaan konsumen akan mempengaruhi loyalitas penumpang pada arah yang sama. Upaya peningkatan kepercayaan penumpang akan meningkatkan loyalitas penumpang maskapai penerbangan Garuda Indonesia, atau sebaliknya.

Tabel 3. Hasil Analisis Regresi Linier Berganda

\begin{tabular}{lccccc}
\hline \multirow{1}{*}{ Model } & \multicolumn{2}{c}{$\begin{array}{c}\text { Unstandardized } \\
\text { Coefficients }\end{array}$} & $\begin{array}{c}\text { Standardized } \\
\text { Coefficients }\end{array}$ & t & Sig. \\
\cline { 2 - 6 } & $\mathbf{B}$ & Std. Error & Beta & & \\
\hline (Constant) & 7,680 & 2,943 & - & 2,609 & 0,011 \\
\hline Kepuasan (X1) & 0,136 & 0,067 & 0,240 & 2,040 & 0,045 \\
\hline Kepercayaan (X2) & 0,211 & 0,082 & 0,301 & 2,560 & 0,013 \\
\hline
\end{tabular}

Sumber: Data primer diolah (2019).

\section{Uji Hipotesis}

\section{Uji t (Pengaruh Parsial)}

Hasil penelitian ini membuktikan bahwa variabel kepuasan penumpang berpengaruh signifikan secara parsial terhadap loyalitas penumpang maskapai penerbangan Garuda Indonesia di Bandar Udara Adi Soemarmo Boyolali. Berdasarkan hasil analisis regresi linier berganda pada Tabel 3, variabel kepuasan penumpang menunjukkan nilai t-hitung 2,040 lebih besar dari t-tabel 0,239 dan nilai signifikansi sebesar 0,045 lebih kecil daripada 0,05. Dengan demikian, variabel kepuasan penumpang berpengaruh secara parsial dan signifikan terhadap loyalitas penumpang maskapai penerbangan Garuda Indonesia di Bandar Udara Adi Soemarmo Boyolali, sehingga H1 dapat diterima.

Hasil penelitian ini sejalan dengan temuan Prasetyo (2013) yang mengungkapkan bahwa kepuasan pelanggan mempengaruhi loyalitasnya pada sebuah swalayan di Purwodadi. Temuan tersebut dapat diartikan bahwa apabila konsumen merasa puas, maka ia cenderung akan lebih setia terhadap produk atau merek yang dikonsumsinya. Hasil tersebut juga selaras dengan penelitian Elrado, Srikandi, \& Edy (2014) yang menunjukkan bahwa variabel kepuasan pelanggan sebuah tempat penginapan atau resor di daerah Batu berpengaruh signifikan terhadap loyalitasnya.

Hasil analisis regresi linier berganda tersebut juga menunjukkan bahwa variabel kepercayaan penumpang memiliki nilai t-hitung sebesar 2,560 lebih besar daripada ttabel 0,239 dan nilai signifikansi sebesar 0,013 lebih kecil daripada 0,05. Dengan demikian, variabel kepercayaan penumpang memberikan pengaruh secara parsial dan signifikan terhadap loyalitas penumpang maskapai penerbangan Garuda Indonesia di Bandar Udara Adi Soemarmo Boyolali, sehingga H2 dapat diterima. Hasil penelitian ini selaras dengan temuan Endarwita (2013) yang mengungkapkan bahwa kepercayaan pelanggan mempengaruhi secara signifikan terhadap loyalitas nasabah sebuah bank di Padang. Penelitian Hairany dan Sangen (2014) juga menemukan bahwa kepercayaan pelanggan berpengaruh signifikan terhadap loyalitas pada LPSBM (Lembaga Pengembangan dan Sertifikasi Batu Mulia) di daerah Banjar. 


\section{Uji F (Pengaruh Simultan)}

Berdasarkan hasil Uji F pada Tabel 4, F-hitung diperoleh sebesar 7,936 dengan tingkat signifikansi 0,001, sedangkan F-tabel dengan tingkat signifikansi 5\% dan derajat kebebasan $(\mathrm{df})=(\mathrm{k}-1)(\mathrm{n}-\mathrm{k})=(3-1)(68-3)=(2 ; 65)$, maka nilai F-tabel diperoleh sebesar 3,13. Dengan demikian, hipotesis ketiga dapat diterima, karena F-hitung $(7,936)$ lebih besar daripada F-tabel $(3,13)$ dengan tingkat signifikansi 0,001 lebih kecil daripada 0,05. Hasil tersebut menunjukkan bahwa variabel kepuasan dan kepercayaan penumpang berpengaruh secara simultan dan signifikan terhadap loyalitas penumpang maskapai penerbangan Garuda Indonesia di Bandar Udara Adi Soemarmo Boyolali. Hasil penelitian ini sejalan dengan penelitian Hairany dan Sangen (2014) yang menyatakan bahwa kepuasan dan kepercayaan pelanggan berpengaruh secara simultan terhadap loyalitas pelanggan LPSBM. Hasil tersebut juga sejalan dengan penelitian Harumi (2016) yang menemukan bahwa loyalitas pelanggan di perusahaan Seiko Laundry Medan dipengaruhi oleh kepuasan dan kepercayaannya.

Tabel 4. Hasil Uji F (Simultan)

\begin{tabular}{lccccc}
\hline \multicolumn{1}{c}{ Model } & Sum of Squares & $\boldsymbol{d f}$ & Mean Square & $\boldsymbol{F}$ & Sig. \\
\hline Regression & 91,399 & 2 & 45,700 & 7,936 & 0,001 \\
\hline Residual & 374,292 & 65 & 5,758 & & \\
\hline Total & 465,691 & 67 & & & \\
\hline Sul & & & & \\
\hline
\end{tabular}

Sumber: Data primer diolah (2019).

\section{Uji Koefisien Determinasi $\left(\mathbf{R}^{2}\right)$}

Hasil uji koefisien determinasi $\left(\mathrm{R}^{2}\right)$ menunjukkan angka sebesar 0,196 atau 19,6\% (Tabel 5). Hasil ini menunjukkan bahwa variabel kepuasan dan kepercayaan penumpang maskapai penerbangan Garuda Indonesia di Bandar Udara Adi Soemarmo, Boyolali mampu menjelaskan variasi pada variabel loyalitas penumpang sebesar 19,6\%, sedangkan sisanya sebesar $81,4 \%$ dijelaskan oleh variabel lain yang tidak digunakan di dalam model penelitian ini. Variabel lain yang mempengaruhi loyalitas konsumen, antara lain emotional bonding (ikatan emosi), choice reduction and habbit (pilihan dan kebiasaan), dan history with company (pengalaman masa lalu dengan perusahaan) (Hasan, 2009).

Tabel 5. Hasil Uji Koefisien Determinasi

\begin{tabular}{cccc}
\hline $\mathbf{R}$ & R-square & Adjusted R-square & Std. Error of Estimate \\
\hline 0,443 & 0,196 & 0,172 & 2,39965 \\
\hline
\end{tabular}

Sumber: Data primer diolah (2019).

\section{KESIMPULAN DAN SARAN}

Berdasarkan hasil perhitungan statistik dalam uji parsial (uji t), variabel kepuasan dan kepercayaan berpengaruh signifikan secara parsial terhadap loyalitas penumpang maskapai penerbangan Garuda Indonesia atau $\mathrm{H}_{1}$ dan $\mathrm{H}_{2}$ dapat diterima. Hasil statistik lainnya yaitu uji simultan (uji F) juga membuktikan bahwa variabel kepuasan dan kepercayaan secara siumultan berpengaruh signifikan terhadap loyalitas penumpang 
maskapai penerbangan Garuda Indonesia atau H3 diterima. Dari hasil koefisien determinasi menunjukkan bahwa kepuasan dan kepercayaan penumpang mampu menjelaskan variasi yang terjadi pada loyalitas penumpang maskapai Garuda Indonesia di Bandar Udara Adi Soemarmo hanya sebesar 19,6\%, sedangkan sisanya sebesar 81,4\% dijelaskan oleh variabel lain di luar model penelitian.

Dari hasil tersebut, manajemen Garuda Indonesia di Bandar Udara Adi Soemarmo, Boyolali perlu mempertahankan kinerja layanan jasa penerbangannya. Upaya peningkatan kepuasan dan kepercayaan penumpang, seperti layanan berkualitas dan efisiensi waktu pada saat pre-flight, in-flight hingga post-flight perlu mendapatkan perhatian serius. Penelitian selanjutnya perlu mengembangkan lebih lanjut model penelitian ini melalui perbaikan pada keterbatasan penelitian, memperbanyak jumlah sampel yang dianalisis, dan meningkatkan response rate responden. Penambahan jumlah variabel yang diteliti juga perlu dilakukan pada penelitian berikutnya.

\section{DAFTAR REFERENSI}

Arzena, D. M. (2013). Pengaruh Kepuasan atas Kualitas Pelayanan dan Kepercayaan terhadap Loyalitas Nasabah PT Bank Mandiri, Tbk. Cabang Muaro Padang. Journal of Chemical Information and Modeling, 53(9), 1689-1699. https://doi.org/10.1017/CBO9781107415324.004.

Boohene, R., \& Agyapong, G. K. Q. (2011). Analysis of the Antecedents of Customer Loyalty of Telecommunication Industry in Ghana: The Case of Vodafone (Ghana). International Business Research, 4(1), 229-240. https://doi.org/10.5539/ ibr.v4n1p229.

Elrado, H. M., Srikandi, K., \& Edy, Y. (2014). Pengaruh Kualitas Pelayanan terhadap Kepuasan, Kepercayaan dan Loyalitas (Survei pada Pelanggan yang Menginap di Jambuluwuk Batu Resort Kota Batu). Jurnal Administrasi Bisnis, 15(2), 1-9.

Endarwita, E. (2013). Pengaruh Kualitas Produk dan Kualitas Pelayanan terhadap Kepuasan dan Loyalitas Nasabah Tabungan Bank BRI Cabang Simpang Empat. Apresiasi Ekonomi, 1(3), 167-180.

Ermawati, E., P. W., Sudiro, A., \& Khusniyah, N. (2016). Pengaruh Kesadaran Merek dan Asosiasi Merek terhadap Ekuitas Merek pada Pelanggan Hypermarket di Kota Malang. Jurnal Aplikasi Manajemen, 14(2), 373-386. https://doi.org/10.18202/ jam23026332.14.2.19.

Fihartini, Y. (2012). Pengaruh Kepercayaan dan Kualitas Layanan terhadap Loyalitas Nasabah Asuransi di Bandar Lampung. Proceeding OJK Harapan Baru Sistem Keuangan Indonesia, Forum Riset Ekonomi dan Bisnis (FRES), Universitas Lampung, Bandar Lampung, 18-19 Desember, 244-250.

Ginting, P. (2005). Pemasaran Pariwisata. Medan: USU Press.

Hairany, E., \& Sangen, M. (2014). Pengaruh Kepuasan dan Kepercayaan terhadap Loyalitas Pelanggan Lembaga Pengembangan dan Sertifikasi Batu Mulia (LPSB) di Martapura Kabupaten Banjar. Wawasan Manajemen, 2(3), 251-260.

Handoyo, S. (2011). Aviapedia: Ensiklopedia Umum Penerbangan. Jakarta: PT Kompas Media Nusantara. 
Hariyatiningsih, A., Suddin, A., \& Ernawati, E.. (2016). Pengaruh Service Quality terhadap Customer Loyalty dengan Customer Satisfaction dan Airline Image sebagai Pemediasi (Survei pada Pengguna Jasa Maskapai Penerbangan Garuda Indonesia Airline di Kota Surakarta dan DIY). Jurnal Manajemen Sumber Daya Manusia, 10(2), 143-160.

Harumi, S. D. (2016). Pengaruh Kepercayaan dan Kepuasan Pelanggan terhadap Loyalitas Pelanggan di Perusahaan Seiko Laundry Medan. Analitika, 8(2), 115128. https://doi.org/10.31289/analitika.v8i2.875

Hasan, S. (2009). Pengaruh Kualitas Layanan, Citra, Nilai dan Kepuasan terhadap Loyalitas Pasien (Studi pada Industri Rumah Sakit di Kota Makassar). Aplikasi Manajemen, 8(1), 256-263.

Kotler, P. (2010a). Manajemen Pemasaran. Jakarta: Erlangga.

Kotler, P. (2010b). Prinsip-Prinsip Pemasaran (Sembilan). Jakarta: PT Indeks Gramedia.

Laely, N. (2016). Analisis Pengaruh Kepercayaan dan Harga terhadap Loyalitas Pelanggan Dimediasi Kepuasan pada PT Telkomsel di Kota Kediri. Ilmu Ekonomi \& Manajemen, 3(2), 61-74.

Maharani, A. D. (2010). Analisis Pengaruh Kepercayaan dan Kepuasan terhadap Loyalitas Nasbah Tabungan Bank Mega Semarang. Tesis. Universitas Diponegoro Semarang.

Muktiono, K. V. (2014). Pengaruh Kualitas Pelayanan Inti dan Kualitas Pelayanan Periferal terhadap Kepuasan Pelanggan serta Dampaknya terhadap Minat Word of Mouth pada Bengkel PT Nasmoco Gombel Semarang. Tesis. Universitas Diponegoro Semarang.

Nidyatantri, N. M. M., Suryawardani, I. G. A. O., \& Agung, D. G. (2016). Pengaruh Kepuasan dan Kepercayaan terhadap Loyalitas Konsumen Kedelai Jepang Edamame: Pendekatan Structural Equation Modeling. E-Journal Agribisnis dan Agrowisata (Journal of Agribusiness and Agritourism), 5(1), 1-10

Nugroho, A., \& Sudaryanto, B. (2013). Pengaruh Kinerja Layanan, Kepercayaan dan Kepuasan terhadap Loyalitas Konsumen dalam Menggunakan Jasa Pengiriman Barang. Diponegoro Journal of Management, 2(3), 1-9.

Prasetyo, W. B. (2013). Pengaruh Kualitas Pelayanan, Kepercayaan dan Kepuasan terhadap Loyalitas Pelanggan (Studi pada Swalayan Luwes Purwodadi ). Jurnal Manajemen Pemasaran, 1(2), 1-13.

Priyatno, D. (2010). Teknik Mudah dan Cepat Melakukan Analisis Data Penelitian dengan SPSS dan Tanya Jawab Ujian Pendadaran. Yogyakarta: Gaya Media.

Reyhan, A. (2013). Analisis Pengaruh Kualitas Pelayanan, Fasilitas, dan Kepercayaan terhadap Kepuasan Konsumen. Ekonomika, 1(2), 12-39.

Soegoto, A. S. (2013). Persepsi Nilai dan Kepercayaan terhadap Kepuasan dan Dampaknya terhadap Loyalitas Konsumen. Jurnal Riset Ekonomi, Manajemen, Bisnis dan Akuntansi, 1(3), 1271-1283.

Sugiyono, S. (2010). Metode Penelitian Bisnis. Bandung: Alfabeta.

Winahyuningsih, P. (2010). Pengaruh Kepercayaan dan Kualitas Pelayanan terhadap Kepuasan Konsumen pada Hotel Griptha Kudus. Sosial dan Budaya, 3(2), 1-17. 